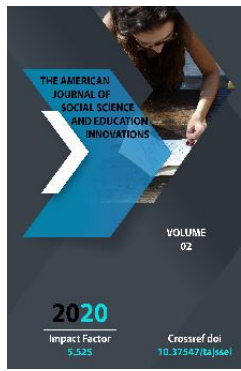

\title{
The Specific Nature Of Mythological Legends
}

\author{
Rizoeva Mehriniso Abduazizovna \\ (Phd) Senior Lecturer Of The Department Of Uzbek Literature, Navoi State Pedagogical \\ Institute (Uzbekistan)
}

Journal Website:

http://usajournalshub.c

om/index,php/tajssei

Copyright: Original

content from this work

may be used under the

terms of the creative

commons attributes

4.0 licence.

\section{ABSTRACT}

The article discusses the problems of mythological myths and their internal types according to the scope of the subject and comments on the essence of the interpretations on this issue.

\section{KEYWORDS}

Mythological legends, myth, cosmogonic legends, anthropogenic legends, ethnogenic legends, folk calendar related legends

\section{INTRODUCTION}

It is known that mythological legends are classified as a separate subtype of Uzbek folk legends, which has a unique series of images, plot system and way of expressing reality. The "mythological legends are syncretic in structure and carry the characteristics of the myth and fairy tale genre. Mythical events are interpreted in the crust of the religion of fire and Islam. The protagonist reflects the characteristics of the mythological subject. This feature is even more evident in image interpretation, movement, and relationships. The plot is based on a fantastic fiction and plays a decisive role in resolving the fantastic conflict. "[1] The syncretism inherent in mythological legends is determined by the fact that in these kinds of prose works the most ancient mythological beliefs, different religious views and folk beliefs are conveyed through different motives and interpretations of images of a fantastic nature. 


\section{MATERIALS AND METHODS}

The specific nature of mythological legends in Uzbek folklore is determined by their direct connection with the ancient system of myths and beliefs. As "one-story fantasy stories of cosmogonic, etiological, anthropomorphic nature, which provide information about the beginning of the material world, explain the emergence of things related to nature and social life, are called mythological legends." [2] There is a lot of scientific and creative experience in the study of mythological legends in world folklore, in particular, M.R. Khalidova, V.F. Davidyuk, I. Khalipaeva, L.A. Karieva, Yu.M. Murtuzaliev, N.M. In the works of such scientists as Kurbankhanova, N.Tursunova [3], N.Yarashova [4] serious scientific views on the peculiarities of mythological legends were put forward. Mythological legends differ from toponymic legends, which explain the reasons for the origin of a particular place name, as well as historical legends, which tell real-life events and great people who played an important role in the past of our people. These different characters are as follows.

1. The historical and genetic basis of mythological legends is directly related to myth. The main feature of Uzbek mythological legends is that they are based on myth. In such legends, heroes such as Adam Ad, Hubbi, Olangasar, Khojimadoliq, Avj ibn Unuq, Haji Mulk, totem animals such as wolves, deer, patrons such as Hizr, Ghoib ota, mythological birds such as Anqa, Semurg, Murg Qori, Humo characterized by the acquisition of essence.

1. In mythological legends, which arose as a result of the historical development of myths as a result of the diffusion of oral prose genres into the plot system, such animistic imagery has become an epic element that serves to explain the reasons for the transformation of man into an animal through moral and ethical views.

2. It is known that among our people there is a tradition of avoidance as in the case of the owl. The squeaking of Olashakshak (bird's name) landing on the trees, the unpleasantness of his voice, and the fact that he could not find a permanent place somewhere, gave rise to the epic interpretation associated with comparing his symbolic image to that of a squirrel. The essence of the mythological myth is that one of the features that contradicts the normative moral views in society is the condemnation of slander and the expression of a negative attitude towards those who have acquired this bad habit. These socio-ethical views are expressed through an epic plot based on the motive of evolution, which is based on an animated myth.

3. Mythological legends have a plot system that incorporates ancient imaginations and religious beliefs. Mythological myths have preserved the remnants of the beliefs and religious imaginations of ancient people, and such archaic beliefs have been subordinated to the ideas of Islam and interpreted as a means of expressing the moral and ethical criteria of society. For example, among our people there are rituals such as turning the turtle upside down when it is dry and hanging it on a hammer with a rope tied to the turtle's leg. This ritual, performed with a tortoise, has a magical character 
and is in fact linked to ancient beliefs that this animal cult is associated with the element of water. Because in ancient mythology, the tortoise was also thought of as the "owner" of all the water in the universe, a god who controlled the order of precipitation.

4. In the Avesto, the symbolism of drought, and in the mythology of the ancient ancestors of the Turkic peoples, the mythical description of the tortoise as a "celestial being floating in the ocean of the universe" has become a mythological myth and has survived to the present day.

5. 2. The plot of mythological legends is characterized by the expression of the etiological content, which serves to explain the process of creation of certain things-events. One of the main features of such legends "inherited" from ancient myths is the presence of an etiological motive in the construction of the plot. It is known that the ancient myths arose as a result of our ancestors' desire to understand the cause of certain natural phenomena, things in existence, and the etiological content of the mythological legends that emerged as a result of the epic diffusion of this mythological arsenal. As K. Imamov rightly points out, "the motives that make up these kinds of stories are distinguished by the nature of the creation of divine phenomena. This feature is the special qualities, the defining properties of the studied legends.

For example, the legend of the "Spot of the Moon" explains the reasons for the peculiar appearance of the night light by means of imaginary fiction. Ancient people created a mythological myth by analogy with the simulation of shadowy areas of the moon's surface that look like spots when viewed from the ground. A unique plot is created based on a fantastic interpretation of a seemingly celestial phenomenon through simple details.

6. The active participation of the traditional evolutionary motive in the plot construction of mythological legends. It is known that most of the Uzbek folk mythological legends have a short plot structure, often based on one or more motives, describing the creation, emergence, emergence of certain natural phenomena, celestial bodies, fauna and flora, man, earth, universe and other things. popularized as built epic works. Therefore, in this type of myth, the transition of characters from one state to another, that is, the motive of evolution, is very common. Evolution is the core motive of the plot of the mythological legend. For example, one of the stars that rises in the west before sunset and soon sets is Umrizoya, and there is a legend among the people about this star: "In ancient times, a girl fell in love with a poor boy. The guy also loves the girl. One day they were about to get married when the young man said, "Marry me this girl!" he said to the judge. The judge fell in love with the beauty of the girl who came to teach marriage and wanted to marry her himself. Then the girl prayed to God. His supplication reached God, became a star, and flew into the sky. That's why this star is called Umrizoya. " [5]

The motive of the girl becoming a star is associated with mythical-animistic views about the connection of the human soul to 
the star, and the evolutionary motif shown in the legend as the cause of the celestial body serves to condemn evil and glorify virginity, honesty, purity, loyalty.

The historical foundations of the evolutionary motif in mythological myths are based on animistic notions that the soul can manifest itself in the form of various phenomena and in various forms. According to folklorist $G$. Akramov, the phenomenon of transformation ("oborotnichestvo") based on the system of animatism is very common in the mythology of nature. "The Smart Girl" (the king takes the form of a blue reed), "The son of a chemist rich man" (eating an apple, turning into a pig), "Snake Brother" (mythical tales such as "falling into a rock, falling back"), "Magic apple" (apple that blooms at night and ripens during the day) contain elements of advanced, higher stage of nature mythology. They have an animated image and interpretation. These elements are at the level of the remnants of some animated imagery and may not have taken the form of a plot or a motif."

5) The syncretic nature of mythological myths.

Well-known folklorist K.Imamov said that "legends narrated on the basis of myths are distinguished by their syncretic character. Myths created by our ancestors, who unconsciously had an emotional reaction to reality, are primitive about primitive rituals, beliefs, religious beliefs, and existence. it meant that knowledge was reflected in itself as a whole. We see that the inherent syncretic nature of the myth is also reflected in the myths formed on the basis of myths.

The main function of the myths was to strengthen the belief in a particular religious belief. Although the main function of these types of myths is to convey to the listener information about the current state of being by narrating certain information of a cosmogonic, etiological, or eschatological nature, it also strengthens belief in certain religious beliefs, cults, gods, deities, and pir. it also serves to form a belief in one or another event.

The syncreticity characteristic of mythological legends is also determined by the fact that the composition of a particular epic plot consists of a collection of several different myths or mythological notions. For example, the myth of the Milky Way, the cult of twins (brothers Angur and Tangur), the dualistic myth of the struggle between the forces of good and evil (Angur and Tangur's prey fight), the cosmogonic myth of the construction of celestial bodies by the creator-hero It has a syncretic character, as it is formed by the addition of myths about the (emergence of the Milky Way) and the separation of earth and sky in the primary cosmos by the demiurge (the sticks of Angur and Tangur slip into the sky).

6) Conciseness of the plot of mythological legends and uncomplicated composition of motifs. Because the process of creating mythological myths is relatively old compared to other types of myths, in the early stages of epic thinking the tradition of conveying reality in a concise form, mainly conveying certain information through a one- or two-episode plot, prevailed. During the development of epic thinking, as the principle of large-scale artistic representation of reality became stronger, the plot structure of the legend genre became more complex, as can be seen in the examples of historical legends created in relatively recent times. 
Among mythological legends, there are even examples based on a single motif. For example, in the mythological legend of the star "Libra", the fact that the celestial body consists of three stars at equal distances from each other, made it possible to make a mythopoetic interpretation based on the likeness of the scales.

Mythological legends are characterized by the fact that the dimensions of time and space are not historically and ethnographically specific, the time coverage of reality is retrospective, that is, the description of events imagined in the past, as well as the mythological nature of the main character system.

\section{CONCLUSION}

Summarizing the ideas expressed in the first chapter of this dissertation, devoted to the study of the peculiarities of mythological legends, the genesis of the plot system and the specifics of this type of oral prose stories, the following general conclusions were drawn:

1. Uzbek folk prose consists of various genres, and in its epic system works of the genre of myth play a significant role. According to the scientific classification recognized in world folklore, legends are divided into such types as historical, toponymic and mythological. Legends of each type are characterized by epic features, plot construction and the uniqueness of the composition of the images. In particular, mythological legends are distinguished by the fact that they reflect ancient ideas and beliefs.

2. The process of formation of mythological legends is directly related to the epic diffusion of ancient myths and the reinterpretation of mythology as an archaic form of perception of reality as a result of the emergence of epic thinking. The place of myths in the genesis of the mythical genre is also determined by its functional nature as the core of epic motifs. The plot series of Uzbek folk mythological legends emerged as one of the important links in the context of epic plots in the folklore of the peoples of Central Asia.

3. The plot of mythological legends is compact in form, the composition of motifs does not have a complex structure, embodies ancient ideas, beliefs, serves to strengthen the belief in cults, gods, gods, patrons, acquires a syncretic nature of the way of reflecting reality and the historical differs from other types of legends in that it is formed as a continuation of succession.

4. Mythological legends are older than other types of legends in terms of the period of their creation, and emerged as an expression of the beliefs of the primitive and tribal stages of human history. Mythological legends are also archaic because they contain archaic religious views - totemism, animism, shamanism, fetishism, magic, ancestral cults, belief in cults of nature, and generalized notions of the universe, man, gods, gods, heroes-titans, demiurges, patrons. -reflecting the beliefs of the tribal period.

Mythological legends are associated with the creation of the universe and man, the lights of the sky, natural phenomena, the appearance of plants and animals, imaginary characters of supernatural nature - gods, gods, creators- 
heroes (demiurges), pirs, gods, forces of good and evil events are also short-story oral prose stories that express beliefs about the beginning and end of the universe in the form of religious beliefs. This type of myth is characterized by the fact that the listener performs an informative function, which consists in the formation of a particular belief, the strengthening of certain perceptions, the transmission of certain information about the origin of material existence in the universe.

\section{REFERENCES}

1. Imomov K. Myth // Essays on Uzbek folklore. Volume 2 - Tashkent: Scinece, 1989. - p.6.

2. Juraev M. Historical bases of Uzbek celestial legends: Philol. Ph.D. diss. Tashkent, 1996. - p.47.

3. Tursunova N. X. O xudojestvennoy interpretatsii natsionalnyx tsennostey $v$ dramaturgii // International scientific conference XX Ivanov MeMorial lectures. - 2018. - p. 183.

4. Jumayevna Y. N. Linguo culture logical features of metaphors in children's literature (On the example of khudayberdi tokhtabayev's creative work) // ACADEMICIA: An International Multidisciplinary Research Journal. - 2019. - T. 9. - №. 4. - p. 139-145.

5. Folklore archive of the Institute of Language and Literature named after Alisher Navoi of the Academy of Sciences of the Republic of Uzbekistan. Inv.№1829,p.17

6. Ikromova. Gulhida. A. (2020). Developing the speech of primary school pupils through the folklore. ACADEMICIA: An International Multidisciplinary Research Journal, 10(5), 567-571.
7. .Ярашова, Н. Ж. (2019). ПРОЯВЛЕНИЕ ИНТОНАЦИИ У ДЕТЕЙ ПОСРЕДСТВОМ ОБРАЩЕНИЯ. In ТРадИциИ И НОВациИ В профессиональной подготовке и деятельности педагога (рр. 128-130).

8. Jumaevna, Y. N. (2020). Occupation of the child's personal mental status in dialogual speech. Asian Journal of Multidimensional Research (AJMR), 9(5), 405-408.

9. Yusupovich, K. S. (2020). The Emergence Of Religious Views Is Exemplified By The Southern Regions. The American Journal of Social Science and Education Innovations, 2(10), 143-145. 